\title{
A Emergência dos Conselhos Setoriais na Agroindústria Brasileira: gênese de uma governança mais ampla? ${ }^{1}$
}

\author{
Walter Belik ${ }^{2}$, Luiz Fernando Paulillo³ e Carlos Eduardo de Freitas Vian ${ }^{4}$
}

\begin{abstract}
Resumo: $\mathrm{O}$ artigo apresenta uma avaliação dos novos mecanismos de regulação setorial rural implementados na década passada no Brasil. $O$ trabalho é baseado na abordagem estabelecida pelos autores da Sociologia Econômica e da Nova Economia Institucional e são analisadas as diferentes fases pelas quais passou a constituição dos complexos agroindustriais. Com isso, torna-se possível demonstrar que estamos diante de um novo período no qual os diversos setores, como o sucroalcooleiro e o citrícola, vêm se organizado de forma a pactuar os preços e as margens a serem praticadas em cada elo da cadeia. No caso do complexo canavieiro, o sistema Consecana vem obtendo relativo sucesso apesar de descontentamentos pontuais por parte dos fornecedores. Com o funcionamento do Consecana, o setor logrou progredir em outros temas como a questão da disseminação de um padrão tecnológico agrícola e industrial mais avançado, a remuneração dos trabalhadores rurais e até mesmo o preço da terra. No caso do complexo citrícola, o sistema proposto, denominado Consecitrus, ainda está em negociação, mas, devido à baixa legitimidade de representação e o histórico de conflitos entre as partes, dificuldades para a sua implementação podem ser registradas.
\end{abstract}

Palavras-chaves: agroindústria, complexo agroindustrial, grupos de interesses.

Abstract: This article assesses the new mechanisms of regulation on rural sector implemented in Brazil during the last decade. Based on the approach of Economic Sociology and the New Institutional Economics, it was analyzed the different phases which the agro-industrial complexes went through. It was possible to prove that we are seeing a new period regarding the organization of rural sector, as the example of sugarcane and orange

1 Os autores agradecem o esforço do Prof. Paulo Waquil e da Alessandra da Paz, secretária da RESR, que cuidaram pessoalmente da avaliação deste texto, permitindo que um dos editores e autor deste artigo, Carlos Vian, submetesse o artigo à RESR respeitando o sistema de "blind review".

2 Professor Titular do Instituto de Economia e Coordenador do Núcleo de Estudos e Pesquisas em Alimentação da Unicamp. E-mail: belik@eco.unicamp.br

3 Professor Associado do Departamento de Engenharia da Produção da UFSCar e bolsista do CNPq. E-mail:dlfp@power.ufscar.br

4 Professor do Departamento de Economia, Administração e Sociologia Rural da Esalq/USP. E-mail: cefvian@usp.br 
juice complexes showed. In the sugarcane case, the Consecana system has been successful, except for some situational disruption of some farmers. In the same way, the Consecana has allowed the whole sector to advance on further subjects, such as the spreading of a new agricultural and industrial pattern, the rural workers remuneration and the sugarcane land prices. As for the citrus case, the proposal system named Consecitrus is now under discussion, but due to the low legitimate of representation and the historical disputes, there would be much more difficulties to its implementation.

Key-words: agroindustry, agroindustrial complexes, sectorial representation.

Classificação JEL: Q13.

\section{Introdução}

Após o marcante período de formação e consolidação dos complexos agroindustriais ocorrido entre 1960 e 1980 no Brasil, e que contou com a tutela e regulação do Estado, ocorreram importantes mudanças na conjuntura e na composição interna de interesses na condução da agropecuária brasileira. Trata-se de um processo que ainda está em curso, em que já se observam transformações no funcionamento de alguns setores. Isso estabelece, por sua vez, novos determinantes para as políticas públicas. Para exemplificar esse argumento, este trabalho apresenta os casos dos emergentes conselhos setoriais agroindustriais que estão se firmando como arenas privilegiadas para as orquestrações e pactos de preços e normas de funcionamento. A principal referência nesse campo é a experiência pioneira do Consecana (Conselho dos Produtores de Cana-de-Açúcar, Açúcar e Álcool do Estado de S. Paulo).

Novos elementos têm contribuído para que os complexos agroindustriais de citros, leite, carne, café, entre outros, passem a adotar também mecanismos de orquestração com ênfase nas fixações de preços e nas distribuições de ganhos de produtividade de forma independente da antiga mediação do Estado. Essas tendências, que serão detalhadas ao longo desse texto, refletem os seguintes elementos presentes nos últimos anos: a) mudanças na conjuntura econômica com a abertura externa e a introdução do sistema de taxas de câmbio flutuante; b) maior organização dos setores compradores dos produtos e subprodutos dos complexos agroindustriais; c) concentração industrial acompanhada pela centralização de capitais nos complexos agroindustriais e d) crescentes conflitos das empresas processadoras agroindustriais com os segmentos a montante e a jusante das cadeias.

Seguindo o exemplo do Consecana, a proximidade da criação de outros conselhos poderá posiciona-las como instituições setoriais balizadoras e complementares aos contratos de negociação entre processadoras agroindustriais e agricultores. Por outro lado, existe a possibilidade de que estes conselhos passem a representar mecanismos de governança mais amplos, no sentido de não se colocarem atrelados unicamente às preocupações de disputas cotidianas entre indústria agroprocessadora e agricultura fornecedora de matérias-primas. Há uma série de consequências e desafios, provocados pelas consolidações dos complexos agroindustriais no Brasil, que podem ser objeto de preocupação desses novos conselhos setoriais.

O presente artigo tem como objetivo mostrar a arquitetura montada em torno desses conselhos agroindustriais no Brasil à luz da experiência do Consecana, no setor sucroalcooleiro, e das tentativas de formação do Concecitrus, no setor citrícola. Com isso, pretende-se destacar que o modelodepactuaçãointroduzidonaagroindústria canavieira está se disseminando para outros complexos. Ao mesmo tempo, o trabalho pretende avaliar as possibilidades de que esses mecanismos possam ir além, não só regulando contratos como também estabelecendo padrões de produção e de tecnologia a serem adotados 
por todos os atores envolvidos na agroindústria e no processamento de matérias-primas da agropecuária. Esse aspecto é importante porque a construção do Consecana está se tornando uma referência para outros complexos agroindustriais brasileiros, como se discute atualmente no caso citrícola. Essa questão deve ser examinada de modo a contribuir na discussão sobre os modos de estruturar e operacionalizar esses conselhos setoriais agroindustriais.

Para que os objetivos descritos acima fossem atingidos, os autores adotaram como metodologia de levantamento de dados a revisão bibliográfica de artigos, livros e monografias sobre a evolução da coordenação no complexo canavieiro e no complexo citrícola. Além disso, foram consultados periódicos e informes sobre os dois setores, sites das organizações de classe, jornais de grande circulação, entre outras fontes de informação, para levantamento das posições e críticas sobre o assunto. Também foram realizadas entrevistas com representantes dos setores que apontaram suas visões sobre os pontos fortes e fracos do sistema do Consecana e os principais conflitos. A análise dos dados foi feita na forma de estudo de multicasos, ou seja, cada caso é apresentado separadamente para, posteriormente, ser objeto de comparação. Isto permite apontar as similaridades, experiências, avanços e pontos críticos. Foram entrevistados dirigentes do Consecana, representados pela Unica (União da Indústria de Cana-de-Açúcar), e da Orplana (Organização de Plantadores de Cana da Região Centro-Sul do Brasil), em 2010. Ao longo daquele ano e de 2011 foram realizadas entrevistas com a Associtrus (Associação Brasileira de Citricultores), Faesp (Federação da Agricultura do Estado de São Paulo) e com o Departamento de Citricultura da Sociedade Rural Brasileira. Não foram feitas entrevistas com a indústria processadora de suco de laranja, que não se dispôs a atender os pesquisadores. Como contraponto, foi feita também uma entrevista com representantes do Conseleite, que está sendo criado à semelhança dos anteriores. As demais informações foram obtidas por meio de análise de documentos técnicos e relatórios das empresas citadas.
O texto está composto da seguinte forma: após essa breve introdução, a segunda parte apresenta, à luz da abordagem da economia institucional, uma breve revisão sobre as formas híbridas de governança que se tornaram cada vez mais comuns em complementação aos contratos de negociação entre atores produtivos. Nessa mesma seção, há um esforço de reunir outras características institucionais e organizacionais que podem auxiliar nas compreensões dessas governanças híbridas complementares aos contratos, especialmente as alusivas às redes de relacionamento. Para isso, a revisão bibliográfica aproveita a porosidade conceitual existente entre os institucionalismos econômico e político para receber contribuições das duas áreas mencionadas de forma a compreender a estrutura e a funcionalidade de cada conselho setorial destacado.

A terceira parte discorre brevemente sobre o processo de desenvolvimento regulatório na agroindústria brasileira, mostrando a metamorfose ocorrida entre os períodos de regulação estatal e o de desregulamentação. Mostra ainda que esse processo resultou, entre outros, nos crescimentos das governanças contratuais e de integração vertical nos negócios das empresas processadoras agroalimentares no País. Em seguida, o trabalho destaca a dinâmica do setor sucroalcooleiro da região Centro-Sul do Brasil, dando ênfase para a construção do Consecana e a sua caracterização estrutural. O mesmo é analisado na sequência para o caso citrícola brasileiro, um setor que passa por uma fase de redefinições das relações econômicas entre os elos agrícola e processador, tendo como referência a estrutura e a fórmula de definição de preços do Consecana. Essa seção termina com a comparação dos processos de estruturação e operacionalização dos conselhos setoriais sucroalcooleiro e citrícola no Brasil, buscando responder se estes representam mecanismos unicamente complementares aos contratos ou com maior amplitude. Finalmente, terminamos o trabalho com algumas considerações sobre os desafios e implicações das instalações de tais conselhos agroindustriais no Brasil. 


\section{Governanças híbridas e regulação setorial: da complementaridade aos contratos a uma perspectiva mais ampla}

Do ponto de vista mais geral do capitalismo, a regulação da economia teria como objetivo garantir reprodução harmônica das relações de produção (MATOUK, 1981). Entretanto, autores como Aglietta (1979) buscam demonstrar a falência da função normalizadora empreendida pelo Estado e que teve como origem a crise econômica dos anos 20 e 30. Esta falência se baseia na crise da relação salarial, que o autor chama de crise do "fordismo" e na manifestação da tendência declinante da taxa de lucro. O modo de regulação é fundamental para entender como se organiza a sociedade e como se superam os conflitos de forma a garantir a regularidade macroeconômica e a estabilidade do processo de acumulação de capital (BELIK, 1995). O modo de regulação é a base para o estabelecimento do que a Escola da Regulação denomina como regime de acumulação, que é definido a partir da relação salarial, do paradigma tecnológico e do papel desempenhado por instituições como o sistema monetário, as estruturas de concorrência e a natureza do Estado.

Saindo desse plano geral, o conceito de regulação também pode ser aplicado aos estudos setoriais. Louis Malassis, o grande autor clássico no tema da economia agroalimentar dos anos 1960 e 1970, desenvolveu o conceito de "filiere" agroalimentar, que seria amparada em duas pernas: a busca da sua identidade através dos seus produtos, itinerários, agentes e operação e a análise dos seus mecanismos de regulação através da estrutura e funcionamento dos mercados em que participa, intervenção do Estado e planificação (MALASSIS, 1973). Em se tratando de mercados agrícolas, matéria que envolve questões como a de sanidade dos alimentos, a intervenção do Estado na regulação é bastante antiga. Já no século XX, em 1906, o governo norte-americano decreta o "Federal Meat Inspection Act", que talvez tenha sido a primeira legislação instituída para controlar a expansão de um ramo da indústria de alimentos e o primeiro mecanismo de regulação pública setorial direta que se conhece (BELIK, 2010).

Nos tempos atuais, dadas as transformações do capitalismo globalizado com a fragmentação do Estado e a complexidade da sociedade civil, observa-se um processo de transição da regulação estatal para a autorregulação. Esse processo vem se aprofundando com o abandono dos ideais keynesianos e o domínio dos preceitos neoliberais nas conduções das economias a partir do final dos anos 70, em que pese o fato de os países lançarem mão de políticas de investimento público anticíclico em períodos de crise. Curiosamente, em nível setorial, os períodos de crise de mercados nos quais crescia a intervenção pública estão ficando para trás. Dada a atual integração dos mercados e a fragilidade das contas públicas mesmo nos países desenvolvidos, os setores da economia em crise estão sendo abandonados à sua própria sorte, e surgem com muita força esquemas cada vez mais abrangentes de governança setorial.

No plano setorial ou da cadeia produtiva, a adoção de formas de governança híbridas dão formato a um novo arranjo institucional que, por sua vez, vai influenciar o ambiente institucional e que finalmente vai estabelecer os fundamentos legais e normativos para a sua atuação (VAN HUYLENBROECK et al., 2009). Claude Ménard detalhou melhor essa aproximação da mediação contratual com o sistema de preços no momento em que considerou os contratos como uma ferramenta parcial de relacionamento entre os agentes, podendo ser complementada por outras modalidades de controle e coordenação, denominadas mecanismos não observáveis (MÉNARD, 2002, 2004). Segundo o autor, esses mecanismos se cristalizam em uma autoridade, também chamada de ordem ou governança privada. Por autoridade, entende-se a delegação por entidades juridicamente distintas de poder de decisão sobre uma subclasse de suas ações a uma outra entidade (MÉNARD, 2004 apud BOUROULLEC e PAULILLO, 2010). 
Os contratos são considerados formas híbridas de coordenação, colocando-se no amplo espaço que existe entre a hierarquia e os mercados spot. Isso porque no plano da mediação dos negócios entre firmas não existem apenas as coordenações por simples contratos, mas também mecanismos de governança complementares como propriedades contratuais sob confiança, influências e compartilhamentos de recursos em rede, formas distintas de liderança e instituições ad hoc (certificações, símbolos etc) (WILLIAMSON, 1975, 1991; MÉNARD, 2004). Todos esses mecanismos são mediações alternativas ao tradicional sistema de preços que funciona sob o mercado spot ou sob a integração vertical de um negócio.

Dado que o que denominamos de mercado é uma construção social, a chave para o entendimento do funcionamento de cada mercado particular é a forma de coordenação praticada pelos seus participantes. De um lado do espectro, próximo da governança via mercado, a governança híbrida é baseada na confiança. Neste caso, as decisões dos atores privados são descentralizadas. A coordenação é feita por influência mútua e reciprocidade. Do outro lado do espectro, a governança híbrida é uma hierarquia particular monitorada por uma estrutura formal próxima da firma integrada, chamada de instituição ad hoc (como certificações, selos de qualidade etc.). Embora as partes permaneçam independentes, um subconjunto significativo de decisões é coordenado por uma entidade quase autônoma, funcionando como um departamento que apresenta alguns dos atributos de hierarquia. Já na hierarquia, a governança se dá pela autoridade com o relacionamento assimétrico entre as partes e o poder discricionário de quem decide.

Entre as formas hibridas de coordenação podemos identificar casos de exercício da autoridade com base na influência e na liderança (leadership). A influência, também chamada de rede relacional, aceita uma coordenação mais ampla que a confiança, apresentando regras formais e convenções que enquadram as relações entre os agentes e que restringem o risco de oportunismo. Neste tipo de governança, a coordenação funciona como em um clube orquestrador, no qual o controle sobre os parceiros é baseado na história do arranjo, na complementaridade do conhecimento e na conivência social (POWELL, KOPUT e SLITH-DOERR, 1996). Já o arranjo híbrido coordenado por um líder difere da influência ou rede porque os parceiros são mais firmemente monitorados. Ou seja, a leadership emerge quando uma firma estabelece sua autoridade sobre os seus parceiros.

Nesse âmbito da governança privada fica claro que, nas contratações sob confiança entre as partes, o preço é arbitrado e os custos de transação são reduzidos até o limite do que se consegue avaliar. Na medida em que mais especificidades do negócio são conhecidas e o ambiente externo se revela mais hostil, as redes relacionais e instituições ad hoc tornam a governança privada mais complexa. Mas essa complexidade não diminui a importância da necessidade de se tomar os custos de transação como foco central da governança setorial de forma a estabelecer preços e a repartição dos ganhos.

Ménard (2004) defende que certos arranjos institucionais (como as redes ou instituições ad hoc) existem para manter o foco da governança privada nos custos de transação e, obviamente, nos preços. Porém, quanto mais próxima da integração vertical estiver a governança privada, maior será o poder de mercado da empresa coordenadora, colocando em risco a continuidade dos arranjos anteriores. Com isso, podemos afirmar que nem sempre esse arranjo poderá trazer reduções mais expressivas nos custos de transação, mas com certeza é o arranjo que trará maior poder de mercado ao elemento de coordenação.

Com maior poder de mercado, maior será a capacidade da empresa coordenadora em influenciar o ambiente institucional ou a regulação setorial. E essa influência importa porque a concorrência entre grandes empresas não só envolve a disputa por recursos públicos como também uma maior atenção por parte do Estado no desempenho de algumas das suas funções reguladoras. Isso significa que os mercados, não importando quais sejam os arranjos, se intrometem 
na política (BELLUZZO, 2002). Certas estratégias, como alcançar status público para influenciar e efetivar políticas, concentrar interesses de muitos atores, modificar regras e normas ou compartilhar informações, proporcionam igual ou maior significado que as estratégias de governança diretamente ligadas com a produção, como a integração vertical (PAULILLO, 2002). A literatura do institucionalismo político (VAN WARDEEN, 1992; DOWDING, 1985; POWELL, 1990) mostra que a formação de redes e instituições ad hoc vai dar maior complexidade à governança privada e esse movimento acaba por transbordar para outras formas que envolvem, desta feita, a regulação setorial. Assim, importa diferenciar as existências das confianças, redes ou instituições ad hoc no relacionamento setorial. A diferenciação reside nos modos de governança em rede e nos objetivos finais ou alvos dos atores envolvidos. Se novas instituições surgem para complementar os contratos não há alvo novo e a formação do preço (via eficiência dos custos de transação) e a distribuição de ganhos de produtividade de forma independente são os únicos objetivos. Se esse processo leva à gestação de novas instituições é porque pode haver a necessidade de uma abordagem mais ampla para a atuação do setor, que possa ir além da definição de preços e relações comerciais.

Dois casos paradigmáticos de criação de mecanismos setoriais de regulação serão analisados em seguida. Nesses exemplos, os atores buscaram arranjo institucional que favorecesse não apenas a definição de preços de referência, mas também um sistema de consultas e investimentos conjuntos que pudessem permitir a ampliação da atuação setorial.

\section{As transformações do padrão de regulação na agroindústria brasileira e as emergências das novas governanças}

A literatura sobre a agroindústria canavieira é muito fértil em descrições sobre os conflitos de interesse entre os agentes produtivos e em tentativas de resolvê-los. Podem ser destacados a experiência dos engenhos centrais, os acordos de comércio e as coligações do açúcar. Como estas tentativas foram infrutíferas, o Estado passou a intervir no setor a partir dos anos 1930, impondo uma série de controles e cotas que atenderam a maioria dos grupos organizados, sem resolver efetivamente os problemas. Estes eventos marcam a entrada do Estado na regulação setorial, o que vai perdurar até os anos 1990 em setores diversos como o canavieiro e o cafeeiro, sendo que já a partir da década de 60 esta intervenção já tinha adquirido novos contornos e preocupações, como a modernização e a inserção externa.

O processo de modernização da agricultura brasileira levou a uma enorme transformação do campo no plano produtivo a partir das reformas de 1964. A elevação notável da produção e os incrementos da produtividade na oferta agrícola são as características mais visíveis deste processo. Mas elas não são as únicas. A transformação não se resume ao plano produtivo, estende-se também ao plano político. A modernização agrícola no País representou, na verdade, a intensificação da intervenção do Estado no setor. Isso resultou na modificação brutal da gestão das políticas públicas para o campo, visto que o Estado passou a disciplinar todos os seus aspectos. O termo "intensificação da intervenção" é justificado pela evolução histórica da regulação da agropecuária brasileira porque, como foi mencionado, desde os anos 1930, o Estado brasileiro já vinha direcionando e zelando pela harmonia de interesses nos diversos setores da agricultura, no melhor estilo do Estado Corporatista (uma das marcas do Estado Novo).

A modernização do campo ocorreu sob o viés conservador da política agrícola em que se manteve a estrutura da propriedade rural, amparada pelos interesses do Estado, dos grandes produtores agrícolas e da indústria e do capital internacional. $\mathrm{O}$ crédito rural a juros subsidiados foi o instrumento mais relevante da modernização durante essa etapa de intensa regulação estatal.

O elemento-chave para o entendimento dessa fase está na força política ou de alavancagem de 
recursos em mãos do Estado (BELIK, 1998, 2001). A regulação estatal objetivou: a) elevar a oferta de alimentos para evitar a alta dos preços; b) modernizar as propriedades agrícolas que tinham condições de financiamento, consubstanciando uma modernização conservadora da estrutura fundiária vigente; c) reduzir as pressões exercidas pelos movimentos sociais no campo e d) criar mercado consumidor para a indústria de bens de produção agrícola, internalizada no País a partir dos anos 1960.

O crescimento agropecuário foi respaldado na sua articulação com a indústria de bens de produção agrícola e, posteriormente, com a agroindústria processadora. A nova fase da agropecuária nacional alterou intensamente a sua face (MARTINE, 1989). Com os crescentes incentivos fiscais e a importação de plantas obsoletas, a internalização do setor produtor de bens de produção agrícola seguiu os passos da implementação do setor de bens de produção industrial e marcou o início do processo de constituição dos principais complexos agroindustriais no Brasil - mais intensamente na região Centro-Sul do País. Esse foi o resultado principal da introdução da política de incentivos que financiava o agricultor a taxas negativas e pagava a indústria fornecedora à vista. $\mathrm{O}$ vetor do dinamismo do setor agrário neste período teria sido a sua capacidade de incorporar tecnologia, viabilizada pelas políticas públicas de compensação ao setor agropecuário.

Os interesses do capital industrial e financeiro, já com as primeiras articulações e objetivos em comum, estavam orientados para o rápido crescimento de segmentos específicos da agropecuária nacional. Eram os segmentos vinculados à oferta agrícola internacional ou integrados a algum complexo agroindustrial. Com isso, os arranjos institucionais particulares de cada complexo agroindustrial foram se intensificando. Podemos identificar também uma segunda fase do processo de regulação, que ocorre nos anos 1980, cuja ênfase não se dá no plano produtivo. Os resultados da modernização compulsória dos anos 1960 e 1970 já haviam consolidado um novo patamar de produção e produtividade para a agricultura, e é no plano institucional que vai ocorrer a grande transformação. Novas associações de interesses por produto foram se constituindo em torno das principais cadeias produtivas, sendo que muitas delas foram organizadas pelas mãos do próprio Estado.

Nesta nova fase, a mudança no padrão de regulação estatal é o aspecto predominante com uma expressiva redução dos recursos e da capacidade de intervenção direta. O exemplo acabado desse período pode ser observado pela articulação das agências públicas do Estado e as organizações de interesses privados de algumas cadeias produtivas a partir do início dos anos 1980 (BELIK, 1998). Esse novo quadro se caracterizaria pela autorregulação que se viu fortalecida em seus poderes de negociação junto ao Estado. Internamente, destaca-se o papel indutor e coordenador do elo industrial, ao mesmo tempo em que enfraquecia a agricultura, uma vez que os agricultores continuavam ainda dependentes do Estado para a realização das suas inversões tecnológicas e produtivas.

Deve-se destacar que as mudanças no campo político ocorridas na década de 80 também contribuem para a mudança do padrão de regulação que estamos apontando. A Constituição de 1988 altera a forma de intervenção do Estado na economia, limitando a sua capacidade de intervenção setorial, o que vai facilitar a extinção do IAA (Instituto do Açúcar e do Álcool), do IBC (Instituto Brasileiro do Café), entre outros institutos, no início dos anos 1990, pelo governo Collor.

Os aspectos de ordem geral que explicam a passagem da fase de regulação estatal na agropecuária para a de autorregulação agroindustrial são os seguintes: a) a crise fiscal e política do Estado; b) a integração dos capitais financeiro, industrial, comercial e agrário; c) o avanço das corporações transnacionais agroalimentares e o surgimento de novas formas de financiamento e d) o amadurecimento organizacional dos prin- 
cipais complexos agroindustriais e de suas redes políticas.

O estabelecimento deste tipo de política caracterizou um quadro institucional preciso: crescimento das formas mais concentradas de capital no elo industrial, a constituição de algumas redes de poder com a integração dos capitais industrial, financeiro, comercial e agrário. Em resumo, a articulação do capital industrial e financeiro promoveu o crescimento do poder econômico e político dos grupos empresariais oligopolistas do período.

Diante dessa transformação do padrão de regulação na agroindústria brasileira, é possível observar que os setores mais organizados lograram ampliar a sua atuação. $\mathrm{O}$ associativismo setorial avançou na indústria processadora tendo em vista a atuação dos grupos empresariais com significativos recursos de poder e elevada capacidade de organização. Esse associativismo alcançou também os segmentos da agricultura, uma vez que a representação corporativista e/ ou formal encontrou grandes dificuldades para concretizar as demandas de interesses cada vez mais específicos e setoriais. Essa movimentação indicou um processo claro de autorregulação ou governança setorial bastante maduro, como se observa nos setores canavieiro, cafés finos, leite, avicultura, entre outros.

A partir de 1990, essas governanças foram sofrendo aprimoramentos e novos mecanismos foram aparecendo para aperfeiçoar a busca dos ganhos de produtividade de forma independente pelos atores com maior poder de mercado (geralmente os oligopólios agroindustriais). Essas novas formas de relacionamento entre os atores setoriais têm levado à redução de custos de transação e a uma maior influência ou determinação sobre os preços dos produtos agrícolas e agroindustriais. Entre esses aprimoramentos estão os desenvolvimentos de redes de influência, da confiança, da liderança e de instituições ad hoc.

\section{A emergência dos conselhos setoriais na agroindústria brasileira: os casos do Consecana e Consecitrus}

A emergência dos conselhos setoriais para negociação de preços da cana-de-açúcar e citros, além de outros produtos agrícolas, nos remete à dinâmica dos institutos setoriais criados na década de 30 durante o período do Estado Novo. O IAA, por exemplo, criado em 1933, exercia um papel de grande destaque na criação de regras de funcionamento setorial, na fiscalização dessas regras e punição dos faltosos, como também na execução de atividades normalmente reservadas à iniciativa privada, como a comercialização e exportação de produtos provenientes do complexo. Vale sublinhar que, até a sua extinção, em 1989, o IAA desempenhava funções características de legislador, polícia, juiz e até mesmo agente produtivo, a exemplo do que acontecia no Instituto Nacional do Pinho, do Café, do Mate, da Borracha e outros que atuavam a partir de uma abordagem de representação de interesses próprios do regime corporatista criado por Getúlio Vargas (ORTEGA, 1998; BELIK, 1998).

Mais tarde, na década de 90, diante da necessidade de conter a inflação e tendo em vista a falta de rumo decorrente do "impeachment" do então presidente Collor de Mello, foram criadas as câmaras setoriais para tentar regular e conciliar os interesses dos agentes produtivos. Mais uma vez, pode-se perceber uma certa semelhança entre as câmaras e os atuais conselhos mas, neste caso, seria importante analisar com um pouco mais de detalhe a gênese e o funcionamento de tais câmaras.

As câmaras haviam sido criadas ao final dos anos 1980, durante o governo Sarney, como uma espécie de colegiado, e deveriam funcionar como assessórias ao ministro de Indústria e Comércio, no sentido de apoiar ações governamentais em torno da melhoria da competitividade dos produtos nacionais. Após dois ou três anos de 
paralisia em vista dos problemas políticos da transição e do afastamento do presidente Collor, os trabalhos foram retomados em 1991 com o objetivo de promover pactos setoriais em torno de fórmulas que pudessem acomodar governo, empresários e trabalhadores em torno de arranjos que contemplassem rebaixamento de impostos, contenção de preços e de reajustes salariais. Tendo em vista o sucesso alcançado pela Câmara Setorial da Indústria Automobilística instalada em 1992 (ARBIX. 1996), foram estabelecidas outras 25 câmaras em torno do MICT (Ministério da Indústria, Comércio e Turismo) (TAKAGI, 2004). Entre estas, só havia uma que tratava de assuntos da agropecuária, que era a Câmara da Agroindústria.

Em 1995, dentro dos objetivos de ampliar o debate sobre a Política Agrícola, agora inserido no marco de estabilidade de preços trazido pelo Plano Real de 1994, o Ministério da Agricultura criou outras 36 câmaras setoriais por produto. Essas câmaras tripartites tinham como objetivo analisar os preços mínimos e os valores básicos de custeio apresentados pelo governo, além de discutir estratégias de exportação, barreiras à importação e outros assuntos ligados ao agronegócio. Segundo Takagi (2000, p. 36), esse modelo logo sofreu um esvaziamento, tendo em vista que as câmaras funcionavam apenas como um espaço institucionalizado de reclamações e demandas junto ao governo, sem resultado prático aparente.

O mesmo movimento foi registrado no estado de São Paulo com a criação de quase 30 câmaras entre 1991 e 1999. Essas diferiam das congêneres federais devido à massiva participação de entidades patronais, cooperativas e associações de produtores, com pequena participação dos trabalhadores mesmo porque não haveria sindicatos de trabalhadores rurais ou da agroindústria organizados por produto, com raras exceções.

Segundo o governo estadual, as câmaras paulistas na agricultura tinham como objetivo assessorar o poder executivo na constituição de políticas, formando uma espécie de cogestão onde o setor privado e o público administrariam recursos em programas de autorregulação (TAKAGI, 2004, p. 36). Dessa arquitetura institucional saíram alguns fundos "públicos" específicos para importantes setores, como o citros, como o Fundecitrus (Fundo de Defesa da Citricultura), para a pecuária, como o Fundepec e para a suinocultura, como o Fundo de Defesa da Suinocultura. Por outro lado, a criação de uma câmara do café, por exemplo, deu institucionalidade a um grupo de empresários que se reunia informalmente e que buscava articular ações diretas, visando a melhoria da qualidade do produto, ações de marketing e o incentivo a novos investimentos (SAES e FARINA, 1999).

O caso dos conselhos setoriais, objeto do presente artigo, difere radicalmente das experiências levadas nas décadas de 30 e 90 . Dois elementos importantes merecem destaque: a) a organização dos conselhos não é uma câmara classista e sim um espaço de representação dos diversos segmentos da cadeia produtiva que tem um único objetivo: pactuar preços e margens entre os diversos elos e promover a expansão da produção e ganhos de produtividade; b) trata-se de uma pactuação privada, entre pares, chancelada pelo poder público com total validade jurídica. Os conselhos passam a estabelecer o monopólio da decisão constituindo um locus de negociação de preços e margens, com ramificações importantes em termos de ação conjunta para o desenvolvimento e difusão de um padrão tecnológico e atividades de lobby junto ao governo, agências reguladoras e mercados internacionais.

No caso do setor canavieiro, outras arenas institucionais foram construídas ao longo dos últimos anos com finalidades específicas $\mathrm{e}$ reunindo os vários agentes da cadeia produtiva. Nesse sentido, podem ser destacadas estruturas de regulação e troca de informações próprias com finalidades diretamente ligadas à gestão setorial como o Grupo de Recursos Humanos e o Grupo de Mecanização. 


\subsection{A gênese do sistema Consecana no estado de São Paulo}

Como dissemos acima, historicamente, o setor sucroalcooleiro nacional tem sido marcado por desavenças entre fornecedores de cana e unidades industriais. Por cinco décadas estes conflitos foram mediados pela regulação e pela intervenção do Estado. Após sua desregulamentação em 1999, a busca pelo equilíbrio dessas relações e a sistemática para determinação dos preços da cana têm ficado a cargo do próprio setor através de suas associações de classe.

As relações entre fornecedores de cana e produtores de açúcar e álcool foram disciplinadas formalmente pela primeira vez por meio do Estatuto da Lavoura Canavieira, promulgado em 21 de novembro de 1941 pelo Decreto-Lei n. 3.855, que formalizava a figura do fornecedor de cana-de-açúcar e a cota de fornecimento, fixada em $40 \%$, junto às unidades industriais. O estatuto assegurou a compra da cota de produção dos fornecedores pelas unidades industriais, ao preço estabelecido pelo IAA com base nos preços do açúcar e do álcool naquela época 5 .

Em 1965, o governo federal interveio novamente devido aos graves conflitos entre fornecedores e usinas. Foi promulgada a Lei n. 4.870 em dezembro de 1965, que vinculou o pagamento da cana-de-açúcar não mais ao preço do açúcar e do álcool e ao rendimento industrial das usinas, mas sim ao teor de sacarose e pureza da cana do fornecedor. O preço da cana seria, então, calculado sobre um valor básico, estipulado a partir dos custos de produção e também de uma parcela referente ao rendimento industrial dos fornecedores que estivesse acima do rendimento médio do estado. Esse mecanismo objetivava incentivar a produção de cana de melhor qualidade e desvincular o preço da matéria-prima dos produtos finais, tentando evitar a escassez

5 Szmrecsányi et al. (2008), analisando a evolução recente do complexo, observaram que a participação dos fornecedores vem se reduzindo a cada safra. Atualmente, a cana de fornecedores não deve passar de $30 \%$ do total moído no estado de São Paulo. Na região Nordeste a participação deveria estar próxima desse patamar também. ou excesso de oferta de cana-de-açúcar devido às oscilações dos preços do açúcar. Ao longo das décadas de 70 e 80 , outras alterações ocorreram, mas os preços da matéria-prima continuaram atrelados à qualidade da mesma.

A década de 90 foi marcada pelo processo de desregulamentação da economia e pela mudança do padrão de coordenação das cadeias agroindustriais. No caso do complexo canavieiro, esta década foi bastante conturbada pelas idas e vindas no processo de desregulamentação, com a queda das cotas e regulação de preços. Os conflitos de interesses entre os representantes da agroindústria e os fornecedores de cana ficaram novamente aparentes e o setor buscou formas de se autorregular neste sentido.

Com a desregulamentação nos anos 1990, as mudanças no ambiente institucional e, em especial a liberação dos preços no setor, causou preocupação entre fornecedores de cana e unidades industriais produtoras de açúcar e álcool. Até a safra 1997/98, o governo ditava o preço de comercialização da cana-de-açúcar, mas, com a liberação dos preços do setor a partir de maio de 1998, houve a necessidade de se criar uma fórmula de remuneração da matéria-prima que pudesse conciliar os interesses de fornecedores e unidades industriais.

Preocupados com a questão de como seriam remunerados neste novo ambiente, produtores do estado de São Paulo, através da Orplana, realizaram visitas a outros países onde o sistema de pagamento da cana-de-açúcar era definido entre produtores e indústrias, sem a participação do Estado.

Nessas missões, os técnicos constataram que na Austrália, África do Sul, Argentina e Bolívia, a forma de pagamento era realizada em função da qualidade da cana-de-açúcar de cada produtor. Já na Tailândia, o cálculo do preço da matéria-prima levava em conta o preço do açúcar nos mercados interno e externo. No México, o produtor era remunerado com base na qualidade média da cana-de-açúcar de cada usina. Na Venezuela, o preço da cana-de-açúcar era estabelecido com base em sua qualidade e também na participação 
no preço final do produto. Em suma, há uma diversidade de práticas nos diversos países canavieiros.

A partir das informações obtidas nos referidos países, ideias foram se delineando para uma nova forma de pagamento a ser sugerida aos fornecedores de cana-de-açúcar do estado de São Paulo. Em meados de 1997, foi constituído um grupo técnico formado por cinco representantes dos fornecedores, indicados pela Orplana, e cinco representantes da agroindústria canavieira, indicados pela Unica.

Surgia, assim, a Câmara Técnica do Consecana, a Canatec. O objetivo do grupo era desenvolver um novo sistema de remuneração para a canade-açúcar e também estabelecer regras para o relacionamento entre fornecedores e unidades agroindustriais. Esse novo modelo foi apresentado na sede da Bolsa de Mercadorias \& Futuros (BM\&F) em 14 de abril de 1998. Entretanto, devido aos sucessivos adiamentos da liberalização dos preços do setor, esse sistema passaria a vigorar somente a partir da safra 1998-99.

O Conselho dos Produtores de Cana-de-açúcar, Açúcar e Álcool do Estado de São Paulo (Consecana-SP) foi constituído em junho de 1999 através da associação da Unica e da Orplana. Deve-se destacar que os trabalhadores não têm representação nesta entidade, rompendo a proposta anterior de mecanismos tripartites de coordenação, como foram as Câmaras Setoriais.

As finalidades do Consecana-SP, definidas em seu estatuto, são de ordem regulatória com o objetivo de garantir a participação nos ganhos da produção para todos os agentes econômicos envolvidos, aprimoramento da qualidade do produto e conciliação de conflitos. Deve-se destacar que, embora o primeiro objetivo reforce o fato de que a câmara representa todos que participam da cadeia, a representação efetiva é de fornecedores de cana e empresários da agroindústria. Governo, trabalhadores agrícolas e industriais e fornecedores de equipamento não participam das discussões.

O Consecana estabeleceu um modelo de precificação da cana, a partir dos preços dos produtos finais, até chegar à matéria-prima.
Esse valor tem sido utilizado para remunerar os fornecedorese, porconsequência, os trabalhadores temporários de São Paulo desde a safra 1998/1999, pouco antes de o setor sucroalcooleiro ter sido completamente desregulamentado pelo Estado, o que ocorreu em fevereiro de 1999. Nesse sistema de pagamento, o cálculo do preço da matéria-prima é feito com base na quantidade de Açúcares Totais Recuperáveis (ATR) contidos na cana-de-açúcar entregue e também com base no preço obtido na venda dos produtos finais (açúcar e álcool), mas não dos subprodutos, das unidades industriais. Este é um dos motivos de conflito sobre o sistema, mas que não impede o seu funcionamento até o momento.

O manual do Consecana é bastante detalhado quanto às regras para determinar a qualidade da cana-de-açúcar, mas, mesmo assim, ocorrem desavenças entre fornecedores e unidades industriais no que se refere à amostragem para coleta do material. Os fornecedores reclamam do direcionamento dos furos da sonda para as pontas da cana-de-açúcar, gerando amostras com mais fibras e menor teor de sacarose, visto que a concentração de açúcares no colmo ocorre da base para a ponta. Assim, caso a cana-de-açúcar não esteja no estágio ótimo de maturação, a ponta terá maior teor de fibra e menor teor de sacarose. Além disso, diversos produtores queixam-se de que os aparelhos laboratoriais nem sempre estão bem calibrados, gerando um clima de desconfiança entre fornecedores e indústrias e um constante debate sobre a melhor forma de fazer a amostragem de qualidade.

Durante o ano-safra, o Consecana-SP divulga, até o primeiro dia útil de cada mês, o preço médio estimado do quilo de ATR do mês anterior. Este valor é calculado com base na média ponderada dos preços médios, de mercado interno e externo, efetivamente praticados, dos produtos derivados da cana-de-açúcar nos meses já transcorridos do ano-safra, de acordo com a curva de comercialização destes produtos ${ }^{6}$.

6 Os preços são coletados pelo Cepea/Esalq/USP através de ampla pesquisa com traders, usinas, atacadistas, entre outros agentes. 
A curva de comercialização é traçada com base nas últimas três safras e também com base no mix de produção (percentual de açúcar e álcool) projetado para o ano-safra. As vendas realizadas nas últimas três safras são ponderadas pelos seguintes pesos: $50 \%$ para a última safra; $30 \%$ para a penúltima safra e $20 \%$ para a antepenúltima safra. O mix de produção para o estado de São Paulo utilizado pelo Consecana-SP para o cálculo do preço estimado do $\mathrm{kg}$ de ATR é determinado pela Canatec-SP. Entende-se por mix de produção o percentual de açúcar e álcool (dos diferentes tipos) nos mercados interno e externo. Antes do início da safra, a Canatec-SP realiza projeções de produção para o ano-safra e essas são utilizadas para o cálculo estimado do preço do $\mathrm{kg}$ de ATR até o término do ano-safra. O Consecana-SP divulga, junto ao preço estimado do $\mathrm{kg}$ do ATR, os preços ponderados dos produtos derivados da cana-de-açúcar e o mix de produção que foram utilizados no cálculo. Esse preço serve como referência para o faturamento e para o cálculo dos adiantamentos (parcela do valor faturado) que a unidade industrial pagará ao produtor de cana-de-açúcar, a partir do mês subsequente ao do início da moagem.

Ao término do ano-safra, em 30 de abril, o Consecana-SP divulga o preço médio do $\mathrm{kg}$ do ATR do ano, com base na curva real de comercialização por unidade industrial e no mix de produção efetivo relativos à safra terminada. Estes números refletem a média do setor. No mês subsequente ao término da moagem (mas antes do final do ano-safra), é determinado um preço provisório da cana-de-açúcar entregue ao produtor pela unidade industrial. $\mathrm{O}$ preço provisório deve ser determinado com base no mix de produção da unidade industrial, e não na média do estado, na quantidade de ATR da cana entregue pelo produtor e nos preços médios ponderados dos produtos derivados da cana-deaçúcar, divulgados pelo Consecana-SP. Sobre esse preço, pode ser aplicado um percentual acordado no contrato de fornecimento de cana-de-açúcar para o cálculo do adiantamento dos valores faturados durante o ano-safra.
Este preço provisório tem gerado grande insatisfação e insegurança no momento da entrega da cana-de-açúcar pelo fornecedor, pois o mesmo não conhece o preço efetivo da matéria-prima. Além disso, o percentual de antecipação tem que ser negociado a cada safra entre associação de fornecedores e unidades agroindustriais, gerando mais incertezas e insatisfação. Ainda a título de adiantamento, durante os meses restantes do ano-safra, unidade industrial e produtor devem acordar o pagamento da diferença entre o preço provisório da cana-de-açúcar entregue e os adiantamentos (somados) realizados durante o período de moagem.

Ao final da safra, os preços médios ponderados finais do açúcar e do álcool praticados nos segmentos de mercado interno e/ou externo também são divulgados pelo Consecana-SP até o dia 10 de maio. Esses preços são calculados com base na curva real de comercialização dos produtos de cada unidade industrial durante a safra que terminou. $\mathrm{O}$ preço final ao produtor da cana entregue durante o período de moagem é apurado ao final da safra, com base: a) nos preços médios finais do açúcar e do álcool praticados nos segmentos de mercado interno e/ou externo; b) no mix de produção da unidade industrial compradora; c) na participação, expressa em forma percentual, do custo da matéria-prima no custo de cada um dos produtos do mix da unidade industrial; d) na quantidade de ATR entregue durante a temporada pelo produtor de cana-de-açúcar. Apurado o preço final da cana-de-açúcar entregue, o ajuste das obrigações pecuniárias devidas ao produtor será feito, com base no preço final e nos adiantamentos efetuados ao longo da safra.

No caso de a unidade industrial e o produtor de cana-de-açúcar optarem por adotar o sistema Consecana-SP na realização de seus negócios de compra e venda da cana-de-açúcar, os mesmos devem aceitar as regras contratuais mínimas dispostas no regulamento. Contudo, cada unidade industrial deve pagar ao fornecedor pela matéria-prima com base em seu mix de produção. Assim, existem diferenças 
na remuneração dos fornecedores de unidades próximas. Os fornecedores têm demonstrado descontentamento, alegando que as unidades pertencentes às indústrias nas quais o ATR foi mais baixo estariam se beneficiando, em detrimento dos fornecedores. Contudo, isso pode estar refletindo diferentes estratégias de produção e comercialização das indústrias.

A revisão completa do sistema Consecana-SP e sua atualização, se necessário, são previstas em seu regulamento, podendo ser realizada a cada cinco anos. De fato, a revisão deveria ter sido feita na safra 2004/05, mas só foi finalizada em 2006. Uma nova rodada de discussões e atualização se iniciou em 2011. As principais queixas de produtores dizem respeito à necessidade de maior participação da matéria-prima no custo final dos produtos (açúcar e/ou álcool), falta de acesso de produtores às decisões das unidades industriais no momento da comercialização dos produtos e inexistência de uma forma efetiva de se verificar os números do fechamento que irão compor os preços da matéria-prima. Nesse contexto, produtores salientam que apenas as unidades industriais têm o poder de decisão, o que exerce impacto direto no preço final da cana-de-açúcar. Assim sendo, o modelo exige transparência, confiança e troca de informações.

Bortolleto (2005) analisou os pontos fortes e fracos do Consecana. Como primeiro ponto positivo do sistema Consecana, o autor cita o fato de o mesmo permitir aos fornecedores de cana-de-açúcar a participação na variação do preço do produto final. Apesar de estar sujeito às oscilações desfavoráveis, foi um avanço importante o fato de o produtor da matéria-prima poder usufruir de preços favoráveis nos mercados de açúcar e álcool, como ocorreu no sistema de pagamento da cana-de-açúcar pelo teor de sacarose (preço da cana pago pela quantidade e qualidade).

Outro ponto forte é que o modelo contempla a qualidade da matéria-prima, incentivando o produtor de cana-de-açúcar a buscar novas tecnologias para melhorar a qualidade de sua produção. Ademais, para ambas as partes há garantia de comercialização da cana-de-açúcar através de um contrato e essa garantia é importante para o fornecedor, uma vez que o mesmo não corre o risco de não conseguir vender seu produto numa situação de abundância da matéria-prima. Do lado da indústria, a garantia de compra da matéria-prima permite um melhor planejamento de suas atividades durante a safra e também reduz o risco de a indústria não conseguir adquirir cana-de-açúcar em situações de escassez. De modo geral, o aspecto positivo do modelo é a garantia de obtenção de financiamentos no mercado externo pelas indústrias, mediante a apresentação do contrato de compra e venda de cana-de-açúcar, que comprova a existência da matéria-prima a ser processada.

Em relação à abordagem das representações de interesses, pode-se citar ainda como um ponto forte do sistema Consecana o fato de o modelo ter sido constituído através das associações de fornecedores e indústrias, o que garantiu maior poder de negociação para produtores de cana-de-açúcar. Uma vez que as propriedades agrícolas são pulverizadas, as negociações individuais junto à agroindústria canavieira poderiam reduzir o poder de barganha dos fornecedores na constituição do modelo. Entretanto, o poder de negociação das associações é distinto, havendo divergências na condução dos interesses do setor.

Destaca-se ainda que, a partir da criação do modelo Consecana, o preço da cana-de-açúcar obtido através deste sistema passou a ser utilizado como referência também para o pagamento dos contratos de parceria ou arrendamento de terras no estado de São Paulo. Assim, o sistema é utilizado como referência geral para a precificação da cana comprada pelas usinas, independente de sua origem. Pode-se dizer que o Consecana tem atingido seus objetivos, apesar de existirem conflitos entre os agentes que são dissimulados pela maior força econômica e política da agroindústria canavieira. O fato de ocorrerem revisões esporádicas dá maior confiabilidade ao sistema e permite o avanço do mesmo.

Este sucesso relativo tem incentivado a cópia deste sistema por outras cadeias agroindustriais, embora o sucesso em cada uma deva ser 
relativizado, pois as condições estruturais não são as mesmas. No próximo tópico será descrita a iniciativa de implantação do Consecitrus em são Paulo e, em seguida, discutida sua viabilidade.

\subsection{Consecitrus: um novo ambiente para a velha disputa pelo preço da laranja}

A proposta de se constituir um conselho para a definição do preço da caixa de laranja no setor citrícola brasileiro não é nova e aconteceu em vários momentos. Na atualidade, essa proposta está amparada na experiência do Consecana e nas esperanças da Associtrus e, posteriormente, da CNA e SRB para alcançar preços considerados mais justos, tendo em vista a realidade do mercado internacional de suco de laranja, sendo que nos últimos dois anos a ideia de se constituir um Consecitrus foi finalmente incorporada pela indústria de suco de laranja (representada pela associação chamada CitrusBR. As grandes processadoras (as chamadas $4 \mathrm{C}^{\prime}$ s - Cutrale, Citrosuco, Citrovita e Coimbra-Dreyfuss) passaram a levar essa ideia em conta após o acolhimento da denúncia de formação de cartel industrial feita pela Associtrus junto ao Cade (Conselho Administrativo de Defesa Econômica), e o desdobramento da operação Fanta - realizada pela polícia federal em 2004 . $^{7}$

Com propostas distintas entre as associações representativas da citricultura e da indústria, a orquestração em torno da constituição do Consecitrus ainda está longe de ser um consenso. Em suma, ainda há uma discussão acalorada sobre o tema que motivou a apresentação da proposta, que é a forma de fixação do preço da caixa de laranja. As fórmulas propostas por Associtrus

\footnotetext{
7 A operação Fanta foi realizada pela polícia federal que, sob mandado judicial, teve autorização para vasculhar papéis nos escritórios das grandes processadoras de suco de laranja no Brasil em busca de provas de práticas de cartel na citricultura. Uma série de documentos e computadores foi apreendida e, apesar de correr em segredo de justiça, e com a demora para abertura desses arquivos, as processadoras já propuseram acordos visando o pagamento de multas (indicando concordâncias dos acusados para a existência de cartel). A disputa tem levado a ajuizamentos de ações e pressões políticas.
}

(citricultores) e CitrusBR (indústria de suco) para o cálculo do preço da caixa de laranja são muito diferentes. A Associtrus exige a inclusão das variações dos preços dos varejos internacionais de suco de laranja (na Europa e nos Estados Unidos) e a CitrusBR defende que a variação do preço da commodity (ou do preço FOB Santos) é suficiente. Entre as discordâncias está um processo histórico que envolve disputas contínuas entre os atores coletivos desses dois segmentos do complexo citrícola brasileiro e o aumento da concentração industrial e da integração vertical industrial para trás (do processamento de suco para os pomares). A crescente concentração da produção de laranja entre grandes produtores excluiu mais de 14 mil citricultores nos últimos 13 anos (PAULILLO et al., 2006). Considerando-se que o Consecitrus proposto é o resultado de um processo histórico, importa avaliá-lo como o resultado de três grandes etapas, que foram as seguintes: 1) orquestração para definição do preço da caixa de laranja no interior da Cacex (Câmara do Comércio Exterior), na fase de regulação estatal da agricultura brasileira (anos 70 e início dos 80); 2) efetivação do contrato-padrão (de 1985 a 1990) e 3) fim do contrato padrão (ocorrido informalmente a partir de 1991 e formalmente, a partir de 1994).

Em todas essas etapas, mesmo que surgissem novos aspectos para o processo de orquestração do setor citrícola brasileiro, duas características sempre estiveram presentes: a) somente os representantes das processadoras de suco e dos citricultores participaram das interações (econômicas e políticas) e b) somente a definição do preço da caixa de laranja importou. Todas as demais questões inseridas no processo orquestrador nos últimos 40 anos foram totalmente secundárias. Até mesmo as lutas do setor contra as doenças e pragas nos pomares, incluindo a constituição do Fundecitrus, foram paliativas na disputa para definir o preço da caixa de laranja.

Nas três fases da coordenação setorial citrícola, poucos atores coletivos (tanto da indústria quanto da citricultura) dominaram o processo de orquestração de interesses. Na primeira fase (ocorrida nos anos 60 e 70, durante a regulação 
estatal da agropecuária nacional), o interesse do Estado brasileiro de modernizar rapidamente a citricultura e orientá-la para o mercado internacional de suco foi realizado com muito sucesso.

A orquestração de interesses do setor começou a amadurecer sob a orientação do Estado, visto que o governo federal promoveu a criação de uma arena regulatória específica citrícola, por meio da criação de um comitê específico na Cacex $^{8}$. Nesta primeira fase, sob um ambiente de regulação estatal agrícola, a assimetria de poder foi a de menor intensidade da história citrícola. A debilidade estrutural dos produtores de laranja foi, em parte, encoberta pelas ações do governo federal no âmbito da Cacex: concedendo recursos, viabilizando a modernização produtiva e abrindo espaço para a representação dos interesses da citricultura paulista. ${ }^{9}$

O surgimento das associações de interesses específicos evidencia este movimento. Em 1974 surge a Associação Paulista de Citricultores (Associtrus) e, logo depois, em 1975, a Associação Brasileira das Indústrias de Sucos Cítricos (Abrassucos) é criada. Ambas nasceram fortalecidas: a Associtrus contava com representantes eficientes junto às esferas federal e estadual, alegando aglutinar cerca de 20 mil citricultores em todo o estado de São Paulo. A Abrassucos apresentava um número reduzido de empresas associadas (14 processadoras), mas, por outro lado, representava um poder de negociação significativo,

8 O governo patrocinou o processo de negociação das caixas de laranja no interior da Cacex, sob a coordenação de um comitê específico que administrava os acordos de indústria e da citricultura com o estabelecimento de cotas. O Estado concedeu subsídios para o financiamento e o custeio da produção de laranja e abriu espaço para a representação dos interesses da citricultura; a Federação da Agricultura do Estado de São Paulo (Faesp) ocupou esse espaço como interlocutora no âmbito da Cacex. No caso da indústria, o Estado concedeu empréstimos para a instalação ou ampliação das plantas processadoras e de incentivos fiscais de exportação e permitiu a representação da recémconstituída Abrassucos.

9 A Cacex, de um simples guichê de licenças para exportação, tornou-se um fórum de debates e árbitro dos preços das caixas de laranjas. A transformação da Cacex iniciou um longo processo de amadurecimento institucional, já que as clivagens e articulações dos interesses privados e estatais começaram a ocorrer. porque a estrutura industrial oligopolista já estava instalada no setor.

A existência de poucos agentes industriais e concentrados revelou condições mais fáceis de aglutinação dos interesses do segmento processador. A concentração industrial e o perfil oligopolista propiciaram a efetivação da representação da Abrassucos na Cacex. Assim, já na primeira fase regulatória, o poderio estrutural da indústria estava constituído, porque havia um reduzido número de empresas atuantes, concentração industrial e homogeneidade de tipos e de interesses.

A Abrassucos era mais forte, visto que a industrialização e a conexão com o mercado internacional eram por ela representadas e sua organização interna era profissional. A Associtrus era menos poderosa porque não tinha recursos de poder e concorria com a Faesp, que tinha a representação formal da agricultura em geral. ${ }^{10}$

Oaparecimento das primeiras organizações de interesses específicos no complexo agroindustrial citrícola não justifica a queda instantânea do ambiente institucional corporativista. Na década de 70 estes movimentos indicaram a tendência que se comprovaria somente a partir de meados da década de $80^{11}$. O enfraquecimento da comissão técnica da citricultura da Faesp se iniciou quando o contrato-padrão começou a ser proposto pelas associações específicas da citricultura. ${ }^{12}$

10 Um dos objetivos da Faesp foi o de impedir o crescimento das associações de interesses específicos por produto. A existência da comissão técnica (CT) era fundamental para a sobrevivência da própria Faesp porque era a única maneira de mantê-la vinculada aos agricultores e aos seus interesses específicos.

11 Apesar de a Associtrus e Abrassucos participarem da articulação de alguns interesses básicos, como o preço da caixa de laranja, o controle de doenças e pragas e o combate à barreira comercial no mercado internacional, isso não significou o desaparecimento imediato da Faesp das diversas negociações, porque a sua CT da citricultura permanecia participante e ativa.

12 Três fatos ocorridos em 1978 mostram que uma metamorfose estava por vir. São eles: a) a Associtrus cresce e disputa a representação efetiva da citricultura com a Faesp; b) o Fundo Paulista para a Defesa da Citricultura (Fundecitrus) surge com o apoio do Estado, da indústria e dos citricultores, visto que tem como base o recolhimento de $1 \%$ sobre o preço da caixa de laranja negociada; c) a indústria desrespeita o preço da caixa de laranja estipulado pela Cacex para negociar com a citricultura. 
A partir de 1984, o conflito de interesses entre as próprias empresas industriais tornou-se inevitável. A partir das dissidências entre elas, surgiram a Associação Nacional da Indústria Cítrica (Anic), que passou a representar as empresas Citrosuco Paulista, Cargill Citrus, Bascitros Agroindustrial e Citropectina, e a Associação Brasileira dos Exportadores de Citrus (Abecitrus), responsável pelas empresas do grupo Cutrale. A elevação do poder econômico das maiores empresas processadoras é a principal justificativa para a aceleração do conflito de interesses no próprio segmento, quando houve o rompimento da unicidade da ação coletiva industrial, a dissolução da Abrassucos e o surgimento das novas associações. As dissidências que originaram a Anic e, três anos mais tarde, a Abecitrus, ocorreram na fase de maior concentração industrial. Entre 1985 e 1990, a concentração em torno das quatro maiores empresas se intensificou, atingindo $90,2 \%$ da produção em 1985 e reduzindo-se para 86,7\% em $1990^{13}$.

Entre 1986 e 1990, a orquestração entre indústria de suco e citricultura finalmente atingiu um consenso: os preços unitários das caixas de laranja a serem pagos poderiam apresentar maiores valores, beneficiando os citricultores sem causar contrariedade às processadoras de suco. Esse acordo foi resultado da efetivação do contrato-padrão de 1986, que se desenvolveu com a negociação do preço, com o pagamento da colheita e do transporte e com a busca de reputação e legitimidade dos atores coletivos no setor.

A elevação do poder de negociação de cada associação representante envolvida é a principal explicação para a formalização de um contrato padronizado. No caso da Associtrus, pressionada com o descontentamento de uma parcela de seus associados de Bebedouro e Araraquara, houve uma intensificação de seu trabalho de

13 Foi o período de maior disputa pela hegemonia industrial no território citrícola. As diferenças entre Anic e Abrassucos se deram em função da questão referente ao grau de intervenção do governo federal no setor. articulação com a indústria ${ }^{14}$. A nova disposição da Associtrus significou o passo mais importante para a formalização de um contrato-padrão de fornecimento de laranja entre os citricultores e as empresas de processamento. Com a intensificação das geadas na Flórida, nos primeiros anos da década de 80, os preços da commodity (suco concentrado congelado de laranja) registraram aumentos sucessivos. Os citricultores estavam insatisfeitos com a não participação no novo lucro das empresas processadoras. A Associtrus, em situação delicada com os associados, iniciou um movimento de reivindicação de alterações, de maneira que os lucros advindos da variação do preço do suco, quando da comercialização, fossem divididos entre eles e as empresas.

As reivindicações dos produtores e a atuação incisiva da Associtrus no movimento pressionaram o Estado e a indústria de suco para o estabelecimento de um novo contrato de fornecimento de laranja, que estabeleceu os novos preços com base em alguns elementos, são eles: a) atrelou os preços das caixas de laranja às cotações do suco no mercado internacional; b) incluiu a remuneração da produção industrial e de comercialização (despesas internas e externas, como colheita, frete, custo de industrialização, tarifas portuárias, taxas alfandegárias etc.) e c) incluiu uma taxa de rendimento da fruta, representando o número de caixas necessárias para a produção de uma tonelada de suco concentrado a $65^{\circ}$ Brix (PAULILLO, 1994, p. 87).

A efetivação do contrato-padrão foi inicialmente vantajosa para os citricultores no processo de negociação, na medida em que o preço da matéria-prima passou a acompanhar as cotações do produto final no mercado internacional. Isso não eliminou os fatores de debilidade estrutural da citricultura. A heterogeneidade das produções, o número elevado de produtores e a dispersão territorial dos

\footnotetext{
${ }^{14}$ Isso foi feito a partir de 1985, visto que os produtores descontentes ameaçavam com o provável surgimento de uma nova associação de interesses no cinturão citrícola - o que veio a acontecer em 1988, com a fundação da Aciesp.
} 
produtores prosseguiram ${ }^{15}$. No caso industrial, a chegada do contrato-padrão somente favoreceu a consolidação do associativismo. A existência de poucas empresas, a concentração industrial e a sua homogeneidade foram fatores favoráveis. A partir de 1991, o contrato-padrão se transformou em um instrumento estratégico de algumas empresas processadoras, que o utilizavam como um termômetro do processo de negociação das caixas de laranja com os produtores. $\mathrm{O}$ preço estipulado no contrato continuou sendo a referência para a realização da negociação, mas muitos dos acordos entre produtores e processadoras no cinturão citrícola registraram preços inferiores aos do contrato. Por outro lado, para além do preço estipulado pelo contratopadrão, as referências para o acerto do preço final entre empresa e citricultor passaram a levar em conta também o tamanho da produção, a qualidade da fruta e o número de safras comprometidas (PAULILLO, 2000).

Em relação ao preço-referência do contrato-padrão, o setor entrou em crise no início dos anos 90. A maior coesão da governança citrícola iniciada em 1986 acabou não resistindo a uma sucessão de preços internacionais muito baixos e o contrato-padrão de fornecimento de laranja foi abolido. A indústria de suco, aproveitando o momento, reduziu o preço estipulado no contrato em proporção maior do que a queda da cotação internacional do preço da tonelada do suco, com o objetivo de manter a sua parcela no montante da renda. Com isso, considerando-se a tendência depressiva que se registrou no mercado internacional da commodity, as empresas conseguiram passar a redução por meio da taxa de rendimento fixada das planilhas de custos de industrialização e de comercialização.

15 Em poucos anos, o poder de negociação desta associação, que já enfrentava os problemas da disputa de interesses com a Aciesp, foi abalado'. A Associtrus não conseguiu atingir a maioria dos municípios citrícolas com as suas delegacias regionais, criadas em 1984. A falta de recursos na citricultura impediu também que os objetivos destas associações, de reduzir a dispersão territorial e homogeneizar os interesses, fossem cumpridos.
É neste período que nasce a indignação de grande parcela de produtores de laranja quanto ao cumprimento do contrato e as primeiras tentativas de revisão do sistema. Essas reivindicações iniciaram um movimento que vai culminar na atualidade com a possibilidade de um novo conselho para formação do preço da caixa de laranja (após 2009/10). Desde 1991 existem alguns aspectos discordantes entre indústria de suco e citricultores, que naquela época giravam em torno do contrato-padrão e que se mantêm até hoje. Essas são os seguintes: 1) a consideração das despesas de alíquotas e fretes referentes unicamente ao mercado norte-americano, no qual as taxas são muito elevadas, em contraste com o principal comprador nessa época, que já era a Comunidade Europeia. Ademais, a cotação da Bolsa de Nova York era a única levada em consideração para calcular o preço; 2) os produtores reivindicavam que a taxa de rendimento (caixas de laranja/tonelada de suco) fosse reduzido para a base de cálculo de 250 caixas/tonelada, e não 260 caixas/tonelada estabelecidas pelas indústrias no contrato-padrão ${ }^{16}$; 3) havia sérios desacordos sobre a questão da remuneração da produção e comercialização $^{17}$; 4) as variações dos preços de suco no varejo internacional eram consideradas para formação do preço da caixa de laranja no Brasil (essas variações sempre se mostraram mais elevadas que as mudanças de preços FOBSantos) e 5) produtores alegavam que o preço internacional do suco de laranja era facilmente manipulado na Bolsa de Nova York - pois os maiores produtores brasileiros eram também os

\footnotetext{
${ }^{16}$ Nos primeiros anos do contrato-padrão, a taxa de rendimento considerada era ainda mais elevada (270 caixas/ tonelada) (Maia, 1992). Kalatzis (1998) mostra que este critério tornou-se um elemento de barganha entre produtores de laranja e empresas de suco.

17 A respeito da Remuneração da Produção e Comercialização (RPC), as indústrias apresentavam este custo como um custo comum, sem especificar o valor de cada item para cada empresa. A planilha apresentada era como uma "caixa preta"; o custo de cada processadora era uma informação sigilosa e estratégica, mas todas formavam um preço único, igualando tamanhos, volumes processados e capacidades de indústrias diferentes (VIEIRA, 2003).
} 
maiores exportadores mundiais, com influência crescente também na oferta de suco.

Esses fatores foram decisivos para a extinção do contrato-padrão. O rompimento foi iniciado em julho de 1994 com as ações das associações de interesses da citricultura. A Associtrus e a Aciesp impetraram ação contrária às empresas processadoras na Secretaria do Direito Econômico (SDE) do governo federal. Na acusação, pesavam as práticas de cartel e de imposição de preços por 12 empresas do cinturão citrícola. A ação também foi contrária à intensificação das compras de terras por parte dos processadores para a formação de pomares próprios. Para as associações, as empresas estariam infringindo as regras de comércio e acabando com o ambiente competitivo (SOARES, 1995).

A procedência da acusação oferecida pela Secretaria de Defesa Econômica iniciou o processo administrativo no Cade, órgão julgador do processo. Em outubro de 1995, o Cade aprovou um termo de compromisso entre as empresas para encerrar as práticas de cartel estabelecidas. No acordo, constava que as empresas deixariam de se reunir para a discussão e definição do preço e que seria necessária a apresentação de relatórios trimestrais de cada empresa tratando de sua atuação no mercado ${ }^{18}$.

A intervenção do Cade foi pontual e o objetivo estratégico das associações de interesses dos citricultores não foi realizado completamente, porque este conselho não determinou uma nova política de preços e também não estabeleceu um novo contrato de fornecimento. O compromisso do Cade foi o de atuar unicamente no impedimento do cartel, não interferindo no preço. Também na questão do avanço dos pomares próprios, essa instância não interveio, pois este não foi considerado lesivo à concorrência.

18 As empresas não poderiam mais fixar os preços e as condições para aquisição do produto em comum acordo; não poderiam participar de reuniões realizadas por qualquer associação ou entidade pública, tendo o objetivo de uniformizar as condutas comerciais.
Com o preço livre, a assimetria de poder entre indústria e citricultura se elevou de forma considerável. A dominação industrial se intensificou, tendo em vista o aumento da concentração do segmento processador de suco (que ocorre a partir de 1996). As principais compras foram as das empresas Cambuhy e Montecitrus (pelo grupo Citrovita) e das processadoras de suco da Cargill (pelos grupos Cutrale e Citrosuco).

O aumento da concentração industrial, a redução do número de empresas processadoras, o crescimento da homogeneização de seus interesses e o resultado favorável do preço livre praticado na negociação com a citricultura fortaleceram a Abecitrus. Ao mesmo tempo, as associações representantes dos citricultores se enfraqueceram totalmente. As mudanças ocorridas a partir de 1994 foram totalmente opostas. Enquanto os interesses e os recursos de poder da indústria cresceram, a queda da capacidade de negociação da citricultura foi brutal, o que caracteriza a assimetria de poder e a estrutura extremamente desigual de oportunidades no complexo citrícola.

A capacidade de envolvimento das associações de interesses dos produtores de laranja é muita reduzida, já que lhes falta poder de aglutinação. Essa fragmentação permanece até hoje, com a Associtrus representando cerca de 1.300 citricultores e dividindo a representatividade da citricultura com SRB e Faesp. Já as processadoras, na atualidade, estão representadas pela CitrusBR, que é uma espécie de nova Abecitrus (com as mesmas funções e o mesmo discurso, e que somente desapareceu por causa da denúncia de prática de cartel e das reuniões de combinações de preços que ocorriam em seu escritório).

Assim, o mecanismo de governança pautado em ações coletivas tornou-se irrelevante com as quedas dos poderes de negociação das associações de interesses dos produtores de laranja. A orientação estratégica industrial prevaleceu e 
conduziu um movimento excludente no campo, porque a citricultura esteve orientada unicamente para o fluxo internacional de suco concentrado, de características oligopsônicas, processo esse que se cristalizou nos últimos 20 anos. A formação de um novo contrato de referência, apoiado no que os atores produtivos citrícolas brasileiros passaram a chamar de Consecitrus, não está representando nada novo, porque a indústria só aceita o novo conselho sob as condições que ela quer e defende (um representante da indústria e um da citricultura e nada mais, nem mesmo um ator representante do Estado, sob apoio de uma empresa de consultoria contratada para encontrar uma fórmula comum aos interesses de ambos os lados). Enfim, a proposta de Consecitrus que está na mesa da atual orquestração citrícola brasileira é marginalizante e excludente, porque coloca partes desiguais participando de uma mesma mesa sem a participação ou poder de mediação do Estado.

Marginalizante porque o Concecitrus deverá ser o "conselho dos dois uns", sem incluir os demais atores produtivos e os municípios interessados nas consequências econômicas, sociais e ambientais da produção da laranja, mesmo que seja iniciativa do governo estadual articular as associações de representação de interesses privados do setor por meio de reuniões proximamente. Caso a Associtrus permaneça discordante da proposta da indústria (que é buscar uma fórmula para calcular a remuneração do preço da laranja pautada pelas variações do preço FOB de Santos, o que é facilmente manipulável pelo oligopólio brasileiro de suco de laranja), ela corre um grande risco de ser excluída do conselho e ser substituída pela SRB.

Excludente porque foca somente a formação do preço da laranja num setor que vem mantendo um ritmo impressionante de saída de citricultores do setor (de 26.812 produtores em 1995/96 para 12.627 em 2009, segundo PAULILLO, 2011), de concentração na industrialização de suco (em 2005, as 4 C's detinham $80,5 \%$ do processamento ${ }^{19}$ ) e até de plantio de laranja no campo ${ }^{20}$.

\section{Consecana e Consecitrus: complementaridade aos contratos ou maior escopo?}

Passadas mais de duas décadas da extinção do antigo IAA e um período de intensa desregulamentação das relações trabalhistas e comerciais no ambiente da agroindústria sucroalcooleira brasileira, não se pode afirmar que há uma tendência para a criação de conselhos de autorregulação.

A emergência do Consecana, em meados da década passada, se deu em condições muito especiais em que já existiam canais formais e informais de negociação entre fornecedores e processadores de cana-de-açúcar, visto que já existem organizações de interesses para representar os vários agentes envolvidos há décadas. Acrescente-se a isso o período favorável vivido pelos mercados (interno e externo) dos derivados da agroindústria sucroalcooleira brasileira (açúcar, álcool, energia elétrica). Assim, não é possível afirmar que se trata de um modelo vitorioso porque os conflitos de interesse setoriais ainda estão presentes, porém, de forma latente e

19 Se for considerada aprovada a fusão proposta no fim de 2010 para Citrosuco e Citrovita, o índice de Herfindahl-Hirschman (HHI) do setor processador de suco de laranja saltará de $1.947,13$ pontos para 2.653,5. Um aumento de 706,37 pontos entre a safra 2004/05 e uma safra pós-fusão. Um aumento demasiadamente superior a 100 pontos. Hubbard e O'Brien (2009) argumentam que, em setores com HHI pós-fusão acima de 1.800 pontos (ou altamente concentrados) e que tenham novas fusões que elevem o HHI entre 50 a 100 pontos, essas movimentações podem ser questionadas. Em elevações superiores a 100, as fusões devem ser sempre questionadas pelas autoridades (PAULILLO, 2011).

20 Em 2001, 166 produtores - que representavam 1,1\% do total de citricultores brasileiros - detinham $34,45 \%$ das árvores em produção, sendo que em 2009 cerca de 120 produtores que representavam $0,95 \%$ do total - já detinham $46,6 \%$ das árvores em produção. Incluindo as fazendas pertencentes às quatro grandes processadoras brasileiras de suco de laranja (Cutrale, Citrosuco, Citrovita e Coimbra). 
manifesta em outras áreas. Em algumas regiões existem conflitos sobre preços e qualidade e, em outras, não.

Em alguns setores, como o citrícola, esse conflito é tão exposto que o conselho setorial ainda não se formou completamente. A dominância da indústria de suco no processo de formação do preço da caixa de laranja é intensa e encontra resistência de uma parcela dos produtores.

De outro lado, a experiência do Consecana mostra que vem ocorrendo um processo de aprendizagem dos agentes referente à regulação e à negociação e que foi incentivado pela possibilidade de revisões nos critérios técnicos e nas regras do Consecana. Desse fato é possível extrair dois desdobramentos importantes: a) a formação de uma dependência de rota para formular preços que tem como base o interesse industrial processador (caso do Consecana); b) a experiência do setor sucroalcooleiro transborda para outros complexos agroindustriais sob a emergência de conflitos de interesses antes da consolidação desses conselhos.

O Consecana está disciplinando as relações com os fornecedores e com os arrendatários, se tornando a principal referência de preços no setor. Também se deve destacar que os conflitos foram minimizados pela definição do preço com base nos mercados interno e externo, o que permite a divisão de ganhos e perdas de forma mais igualitária entre os agentes. Na nova rodada que está iniciando deverá ocorrer a incorporação de subprodutos da cana, fazendo com que todos os produtos que geram renda sejam utilizados na definição do preço da matéria prima.

As condições que se apresentam para a constituição do Consecitrus são outras e pautadas por uma enorme desconfiança entre todos os atores envolvidos na industrialização do suco de laranja. Ademais, não há uma unidade ou homogeneidade de interesses pelo lado da citricultura que, por sua vez, negocia com um setor constituído sob a forma de oligopsônio que quer impor a sua proposta.

Essas considerações permitem afirmar que dificilmente acontecerá a vigência de um único modelo de autorregulação para a agroindústria no Brasil. Mesmo porque o Estado não está completamente ausente. Essas novas formas de orquestração ou formatação de pactos de interesses privados agroindustriais acontecem em uma situação de total liberalização dos preços; porém, os governos estaduais e federal ainda apresentam recursos para poder participar das coordenações desses setores (como no grau de adição de álcool anidro na gasolina, nas formações de estoques reguladores de álcool e de suco de laranja, na proposição de um programa de preços mínimos em suas diversas modalidades como ocorreu recentemente para a laranja, alterações de cargas fiscais e tributárias, financiamento público para novas instalações etc.). O Estado ainda tem um peso importante no jogo de interesses dos conselhos de negociação dos complexos agroindustriais brasileiros.

No caso citrícola brasileiro isso já vem ocorrendo. Nas primeiras reuniões para a formatação do Consecitrus ocorreu uma proposta articulada entre os governos federal e do estado de São Paulo para iniciar um programa de preço mínimo para a laranja e consequente formação de um estoque regulador de suco concentrado de laranja. Ou seja, partiu do Estado a formatação do programa regulador e a iniciativa de instalar o programa sob a legitimidade dos representantes privados. Este caso é relevante porque, apesar de ser uma reivindicação antiga da Associtrus, as reuniões para a formatação do Consecitrus ocorreram por iniciativa do governo estadual, que contratou uma empresa de assessoria de planejamento agroindustrial para coordenar as reuniões com as associações de interesses do setor visando implantar esse conselho setorial. Enfim, o caso citrícola atual mostra que ainda há um poder do Estado nesses jogos de interesses setoriais e que esse poder ou participação será flexível conforme a estrutura de cada complexo agroindustrial e a funcionalidade de sua rede de poder.

O caso do Consecana também caracteriza esse processo. Quando o Estado sinaliza que vai financiar estoques reguladores para a indústria 
de álcool brasileiro é porque ele está presente no processo de orquestração de interesses. O que se pode julgar é o tamanho da participação estatal por meio das detenções e usos de seus recursos de poder em cada processo de coordenação setorial. No entanto, o Estado está no setor e tem um peso importante. Em resumo, o Estado no Brasil segue participando do jogo de redes de políticas setoriais, independentemente do seu grau de institucionalidade, abertura e horizontalidade.

É possívelassegurarque essas redes defixação de preços e pactuação de resultados deverão se expandir para outros setores, como embrionariamente já vem ocorrendo. Evidentemente, esse movimento deverá ocorrer em velocidades distintas, sendo que essa deverá depender do maior ou menor grau de organização dos grupos de interesses envolvidos e da possibilidade de participação ativa dos governos. No limite, as expansões dos conselhos poderiam propiciar melhorias em diversas áreas que atualmente revelam fragilidades dos interesses agroindustriais do Brasil em comparação com os mercados internacionais, como é o caso da sanidade, da certificação com atributos de qualidade, da apresentação do produto e da certificação de origem.

\section{Referências bibliográficas}

AGLIETTA, M. Regulación y crisis del capitalismo (La experiencia de los Estados Unidos). Mexico: Siglo XXI, 1979.

ALSTON, L. The "Case" for case studies in new institutional economics. In: BROUSSEAU, E.; GLACHANT, J. M. New institutional economics: a guidebook. New York: Cambridge University Press, 2008.

ARBIX, G. A. T. Uma aposta no Futuro: os primeiros anos da cãmara setorial da indústria automobilística. São Paulo: Scritta, 1996.

BELIK, W. Auto-regulação e Políticas Públicas para o Setor Agroalimentar no Brasil. (Texto para Discussão) Campinas: Instituto de Economia/UNICAMP, 1995

BELIK, W. Estado, grupos de Interesse e formulação de políticas no setor agropecuário brasileiro. Revista de Economia e Sociologia Rural, v. 36, pp 9 - 33, 1998.
BELIK, W. Muito além da Porteira - Mudanças nas Formas de Coordenação da Cadeia Agroalimentar no Brasil. Campinas: UNICAMP, 2001,

BELIK, W. Desenvolvimento Rural e Segurança Alimentar: Contribuições Teóricas para o Desenho e Avaliação de Políticas Públicas. (Tese para o Concurso de Professor Titular em Economia Agrícola) IE/ UNICAMP (mimeo), Campinas, 2010.

BELLUZZO, L. G. Poder e dinheiro. Lições contemporâneas. Folha de São Paulo, Caderno Dinheiro, p. b2, 24/03/2002.

BLANCHOT, F. Les accords inter-firms et concepts associes: une grille $\mathrm{d}$ electure en terme d'interpénétration organisationnelles. In AFRICAN INSTITUTE OF MANAGEMENT SCIENCE WORKSHOP (Proceedings), Heidelber, 1998.

BLOIS, K. Vertical Quasi-Integration. Journal of Industrial Economics, v. 20, n. 3, p. 253-272, 1972.

BOUROULleC, M. D. M. e PAULILlO, L. F. O. E. Governanças híbridas complementares aos contratos no comércio justo citrícola internacional. Gestão $\mathcal{E}$ Produção (UFSCar), v. 17, p. 761-773, 2010.

BRADACH, J. L.; ECCLES, R. G. Price, authority, and trust: from ideal type to plural forms. Annual Review of Sociology, v. 15, p. 97-118, 1989.

COASE, R. H. The nature of the firm. In: WILLIAMSON, O.; MASTEN, S. The economics of transaction cost. England: Edward Elgar, 1999.

COOK, M. L.; KLEIN, P. G. e ILIOPOULOS, C. Contracting and organization in food and agriculture. In: BROUSSEAU, E.; GLACHANT, J. M. New Institutional Economics: a guidebook. New York: Cambridge University Press, 2008.

DAVIS, L.; NORTH, D. Institutional Change and American Economic Growth. New York: Cambridge University Press, 1971.

DOWDING, K. Model or Metaphor? A critical review of the policy network approach. Oxford: Blackwell Publishers. Political Studies, n. XLIII, p. 136-158. 1985.

ECCLES, R. The quasi firm in the construction industry. Journal of Economic Behavior and Organization, v. 2, n. 4, p. 335-357, 1981.

FERRAN, F. Les Determinants a l'achat de produits issus du commerce équitable: une approche par les chainages cognitifs. 2006, 496 f. Tese (Doctorat en Sciences de Gestion). Université de Droit, d'Economie et des Sciences d'AuxMarseille, Marseille, 2006. 
FURLANETTO, E.L. Formação das estruturas de coordenação nas cadeias de suprimentos: estudos de caso em cinco empresas gaúchas (Tese de Doutorado em Administração). UFRGS, Porto Alegre, 2002.

HOUDA, D. Strange forms: still in need for a framework. Management and Organization Research Center, UMR/CNRS $\mathrm{n}^{\circ}$ 7088, 2002. Disponível em: < http:// www.crepa.dauphine.fr/documents/Co/doc_fT8iOP. pdf $>$. Acessado em 15 set. 2008.

JOSKOW, P. L. Price control in long term contracts: the case of coal. 1987. Disponível em: <http://dspace. mit.edu/bitstream/handle/1721.1/29496/MIT-EL-87011WP-19524240.pdf? sequence $=1>$. Acessado em 23 nov. 2007.

KLEIN, B.; CRAWFORD, R. G.; ALCHIAN, A. A. Vertical Integration, Appropriable rents, and the Competitive Contracting Process. In: WILLIAMSON, O.; MASTEN, S. The economics of transaction cost. England: Edward Elgar, 1999.

LAFORGA, G. Dinâmica do Comércio Justo, Associativismo e Agricultura Familiar na Citricultura Brasileira. 2005, 345f. (Tese de Doutorado em Engenharia de Produção). UFSCar, São Carlos, 2005.

LAGENTE, S. Impacto do comércio justo (Fair Trade) da FLO no Brasil: síntese dos relatórios de inspeção da FLO-Cert no Brasil. Institut des hautes Etudes sur l'Amérique Latine, Paris, França, 2005.

MACNEIL. I. R. Reflections on relational contract. Journal of Institutional and Theoretical Economics, v. 141, p. $541-546,1985$.

MALASSIS, L. Economie Agro-alimentaire. Economie de la Consommation et de la Production Agro-alimentaire. v.1. Paris: Cujas, 1973.

MASCARENHAS, G. C. C. O Movimento do Comércio Justo e Solidário no Brasil: entre a solidariedade e o mercado (Tese de Doutorado). CPDA -UFRRJ. Rio de Janeiro, 2007.

MATOUCK, J. Crisis y Porvenir de las Regulaciones In: Agletta et al. Rupturas de um Sistema Economico. Madrid: M. Blume Ediciones, 1981.

McDONAGH, P. Communicative campaigns to effect anti-slavery and fair trade: the cases for Rugmark and Cafe' direct. European Journal of Marketing, v. 36, n. 5/6, pp. 642-666, 2002.

MÉNARD, C. Le pilotage des formes organisationnelles hybrides, Review Économiques, v. 42, n. 3, p. 741-750, 1997.
MENARD, C. Enforcement procedures and governance structures: what relationship? In: MÉNARD, C. Institutions, contracts and organizations: perspectives from new institutional economics. England: Chelteham Edward Elgar, 2002.

MÉNARD, C. Economie néo-institutionnelle et politique de la concurrence: les cas de formes organisationnelles hybrids. Économie Rurale, v. 277, n. 277-278, pp. 277-291, 2003.

MÉNARD, C. Enforcement procedures and governance structures: what relationship? In: MENARD, C.; KLEIN, P. G. Organizational issues in the agrifood sector: toward a comparative approach. American Journal Agricultural Economic. v. 83, n. 3, p. 746-751, 2004.

MÉNARD, C. The economics of hybrid organizations. Journal of Institutional and Theoretical Economics, v. 160, pp. 345-376, 2004.

MÉNARD, C.; SHIRLEY, M. M. Handbook of new institutional economics. New York: Springer. 2005.

MÉNARD, C.; VALCESCHINI, E. New institutions for governing the agri-food industry. European Review of Agricultural Economics, v. 32, n. 3, pp. 421-440, 2005.

MILES, R. E; SNOW C. C. Organizations: new concepts for new forms. California Management Review, v. 28, n. 3, spring, p. 62-73, 1986.

MILES, R. E; SNOW C. C. Organizations: new concepts for new forms. California Management Review, v. 28, n. 3, spring, p. 62-73, 1986.

ORTEGA, A.C. Corporatismo e novas formas de representação de interesses na agricultura: uma abordagem teórica. Brasília: Sociedade Brasileira de Economia e Sociologia Rural. Revista de Economia e Sociologia Rural, v. 36, n. 4, p. 9-37, out./dez. 1998.

PALAY, T. M. Comparative institutional economics: the governance of the rail freight contract. Journal of Legal Studies, v. 13, p. 265- 288, 1984.

PAUliLlO, L. F.; VIEIRA, A. C.; ALMEIDA, L. M. In: In: PAULILLO, L. F. Agroindústria e citricultura no Brasil: diferenças e dominâncias. Rio de Janeiro: E-papers, 2006.

PAULILLO, L. F. Nova fusão no segmento processador de suco de laranja do complexo agroindustrial citrícola brasileiro: razões e consequências econômicas e sociais. Fundação de Apoio Institucional da Universidade Federal de São Carlos. Relatório de pesquisa, São Carlos. 2011.

PENROSE, E. A teoria do crescimento da firma. Campinas: Editora da UNICAMP (Universidade Estadual de Campinas), 2006. (Tradução do original de 1959). 
POWELL, W. Neither market nor hierarchy: network forms of organization. Research in Organization Behavior, vol. 12, 1990, p. 295 - 336.

POWELL, W. W.; KOPUT, K.; SMITH-DOERR, L. Interorganizational Collaboration and the Locus of Innovation: networks of learning in biotechnology, Administrative Science Quarterly, v. 41, p. 116-145.

RICHARDON, G. B. The organization of industry. Economic Journal, v. 82, pp. 883-996, 1972.

RUBIN, P. The Theory of the firm and the structure of the franchise contract. Journal of Law and Economics, v. 21, n. 1, p. 223-233, 1978.

SAES, M. S. e FARINA, E.M.Q. O agribusiness do café no Brasil. São Paulo: Milkbizz, 1999

SZMRECZÁNYI, T.; RAMOS, P. ; RAMOS FILHO, L. O. e VEIGA FILHO, A.A. Dimensões, Riscos e Desafios da Atual Expansão Canavieira. Brasília: Embrapa, 2008 (Texto para Discussão no. 32)

TAKAGI, M. Câmaras Setoriais Agroindustriais, Representação de Interesses e Políticas Públicas. São Paulo: Anablume, 2000.

VAN HUYLENBROECK G. A. Vuylsteke and W. Verbeke. Public Good Markets: The Possible Role of Hybrid Governance Structures in Institutions for Sustainability. In: V. Beckmann, M. Padmanabhan (eds.), Institutions and Sustainability, Springer Science+Business Media B.V.: 175-191, 2009

VAN WAARDEN, F. Dimensions and types of policy networks. Netherlands: Kluver Academic Publishers. European Journal of political research, v. 21, p. 29-52, 1992.

VIEIRA, A. C. Integração vertical, concentração e exclusão na citricultura paulista. São Carlos, 2003, 171 p.. Tese (Doutorado em Engenharia de Produção) - Centro de Ciências Exatas e Tecnologia. Universidade Federal de São Carlos.

WILLIAMSON, O. Industrial organization. New York: Free Press, 1990.

WILLIAMSON, O. Transaction cost economics: the governance of contractual relations. Journal of Law and Economic, v. 22, n. 2, p. 233-261, 1979.

WILLIAMSON, O. Visible and invisible governance. The American Economic Review, v. 84, n. 2, may, p. 323-326, 1994.

WILLIAMSON, O. The economic institutions of capitalism. New York: Free Press, 1998.

WILLIAMSON, O. Comparative Economic Organization: the analysis of discrete structure alternatives. In: WILLIAMSON, O.; MASTEN, S. The economics of transaction cost. England: Edward Elgar, 1999. 